

\title{
THE ECONOMIC ACTIVITIES OF WOMEN IN OTTOMAN EMPIRE
}

\section{DOI: 10.17261/Pressacademia.2016219776}

\section{Nurullah Karta}

Yüzüncü Yıl University. nkarta25@gmail.com

\begin{abstract}
There is no sufficient research that was conducted on the participation of women in the Ottoman Economic system. Most of the time, women in Ottoman State was described considering the framework of harem. However, truth is very different. When the Ottoman records are analyzed, the great economic contribution of Ottoman women to the family and social life has been seen. Of course during the classical period of the Ottoman empire, the given roles to the women is much more limited than the given roles to the men in the social, economic and politic fields. However in the Ottoman social life, the contribution of women to the family budget, the roles in the working life were so important which were thought. The women in Ottoman period have a significant role in the agricultural sector. When the archive documents checked, it has been countered that the women in Ottoman state were involved in agriculture and animal husbandry, gave the direction to the society during the war and peace, worked in the textile industry, home economics. and they had the right of heritage. But it has been that women in England participated in economic activities after the revolution of industry. Women in the West worked in the textile and production sectors in the beginning of the 19th century. But the women in Ottoman state started to work in the fields of industry and service after the Tanzimat. Furthermore, some examples show that women in Anatolia were dealing trade and running stores. For example, in the 17th century, most of the tread production factories in Bursa were owned by women. and the women workers were Muslim and non-Muslim. There were women who had grinder and bakery in their house beside the women who dealt with textile. In this study, it is aimed that to show the role of Ottoman women in the social life and investigated the subjects of women's having properties, the rights of heritage, trading and participating in production by using Prime Ministry Ottoman Archive Documents.
\end{abstract}

Keywords: Ottoman, women, economy, trade, heritage.

JEL Classification: B16

\section{OSMANLI IMPARATORLUĞU'NDA KADININ EKONOMIK FAALIYETLERi}

\section{ÖZET}

Osmanlı ekonomisinde kadının rolü ve çalışma hayatına katılmasına yönelik yapılan araştırmalar yeterli düzeyde değildir. Genellikle Osmanlı kadını harem çerçevesinden bakılarak tanımlanmaktadır. Ancak, Osmanlı arşiv vesikaları incelendiğinde, gerçeklerin çok farklı olduğu, Osmanlı kadınının aile ve toplum hayatına önemli ölçüde ekonomik katkılar sağladığı görülmektedir. Elbette, Osmanlı İmparatorluğu’nun klasik döneminde toplumsal, ekonomik ve politik yaşam alanlarında kadınlara tanınan rol erkeklere oranla daha sınırlıdır. Ancak, Osmanlı toplumsal yaşamında kadınların aile ekonomisine katkıları, çalışma yaşamındaki etki ve rolleri sanılandan çok daha fazla olmuştur. Kadın, Osmanlı'da hâkim sektör olan tarımda ağırlıklı bir role sahiptir. Osmanlı'da kadının tarım ve hayvancılıkla uğraştığı, savaşta ve barışta ekonomiye yön verdiği; ev endüstrisinde tekstil üreticiliği, ipekböcekçiliği ve dokumacılık ile uğraştığı; miras alma ve miras bırakma haklarına sahip olduğu belgelerle tespit edilebilmektedir. Örneğin İngiltere'de kadınların ilk kez sanayi devrimi sonrası ekonomik faaliyet içine girdiği ve ücret olarak ifade edilen ekonomik bir gelir karşılığı bir başkasının hesabına çalışmaya başladığı görülmektedir. Avrupa'da 19. Yüzyılın başlarında kadınlar ağırlıklı olarak imalat ve dokuma sektöründe görev almışlardır. Osmanlıda ise kadınlar Tanzimat sonrası sanayide ve hizmet sektörlerinde işçi olarak çalışmaya başlamışlardır. Ayrıca Anadolu kadınının ticaretle uğraştığını ve ticarethane açtığını gösteren çeşitli örnekler mevcuttur. Örneğin 17. Yüzyılda Bursa'da iplik eğirme atölyelerinin yarısından fazlası kadınlara aittir. Bursa fabrikalarındaki işçilerin çoğu Müslim ve gayrimüslim kadınlardır. Evinde dokuma ve işleme yapan kadınların yanı sıra, değirmen ve fırın sahibi kadınlar da bulunmaktadır. Bu çalışma, Başbakanlık Osmanlı Arşivinde tespit edilen belgelerden hareketle, Osmanlı kadınının toplum hayatında ekonomik rolü, mal sahibi olabilme ve miras alma-bırakma, ticaret yapma ve üretime katılma konuları üzerinde durmayı amaçlamaktadır.

Anahtar Kelimeler: Osmanlı, kadın, ekonomi, ticaret, miras. JEL Sınıflandırması: B16 


\section{GíRiş}

Osmanlı Devleti'nde içtimai ve iktisadi hayat üzerine pek çok çalışma yapılmıştır. Bu bağlamda üç kıtaya yayılmış ve altı yüzyılı aşkın bir süre varlığını sürdürmüş, farklı etnik ve dini kimliğe mensup toplulukları bir arada yaşatma becerisini göstermiş Osmanlı Devleti'nin sosyal, kültürel ve ekonomik yapılanmasında kadınların rolü de dikkate alınmalıdır. Osmanlı Devleti'nin resmi kayıtlarında kadın adlarına rastlamak pek nadir olsa da, arşiv vesikaları ve vak'anüvislerin eserleri iyi incelendiğinde kadınların içtimai ve ekonomik olmak üzere birçok alanda faaliyet içerisinde oldukları görülmektedir.

Osmanlı toplumunda kadının özellikle ekonomiye katkısı hakkında yapılan bazı araştırmalarda, kadınların çalışma hayatında Tanzimat Fermanı'na kadar aktif olarak yer almadığı ileri sürülmektedir. Bu temel bakış açısı, bazı oryantalist söylemler çerçevesinde oluşturulmaktadır. Kaleme alınan ifadeler olumsuz imajların tekrar edilmesinden ibarettir. Osmanlı kadınlarını tasvir eden Z. Duckett Feriman, Miss Julia Pardoe, Lady W.M. Ramsey, Lady Montague ve M. De M. D’Ohsson gibi Batılı seyyahlar da eserlerinde Müslüman kadını olumsuz imajlarla tasvir ederlerken, satır aralarında Osmanlı toplumunda kadının konumunun, Batı toplumlarına göre çok daha iyi yerde olduğu gerçeğine işaret etmekten de kaçınamamışlardır. Az da olsa rasyonel davrandıkları söylenebilir (Sancar, 2010) ${ }^{1}$.

Osmanlı devlet yönetiminin temel dayanağı İslam hukuku idi. Bu bakımdan İslam dinine göre, kadın mal sahibi olabilmekte, ticari sözleşmelere imza atabilmekteydi. Haliyle İslam'da kadın velâyet altında değildi. Hakları aynı zamanda mahkemeler yoluyla korunuyordu (Baş, 2006) ${ }^{2}$. Bu anlamda kadınların ekonomik faaliyetlerine yönelik kısıtlayıcı bir engel söz konusu değildi. Nitekim Müslüman kadınların ekonomik faaliyetlerde bulunması yönünde İslam tarihinden örnekler bulmak mümkündür (Ecer, 2012; Köksal, 2010) $)^{3,4}$.

Tarihin her döneminde, dünyanın hemen hemen her ülkesinde nüfusun önemli bir kısmını oluşturan kadınlar emek yönüyle vazgeçilmez bir üretim unsuru olmalarına rağmen, emek piyasalarındaki varlıkları ve katkıları gerek geçmişte, gerekse günümüzde hak ettikleri yerde değildir. Cinsiyete dayanan iş bölümü her toplumda farklı düzeylerde olsa da temelde; çocuk doğurmak ve büyütmek, ev işlerini yapmak gibi işler fizyolojik ve sosyolojik açılardan kadınların temel görevleri arasında yer alırken, piyasada çalışarak para kazanma işi erkeklerin esas görevi gibi görülmüştür (Özer, M. Biçerli, K. 2004) ${ }^{5}$. Oysa kadın biyolojik hayatın olduğu kadar, sosyal ve toplumsal yaşamın da en temel unsurlarındandır. Kadınlarımız toplum hayatının şekillenmesinde tartışılmaz yere sahiptir. Müslüman Türk kadınının ilk dönemlerden itibaren ekonomik faaliyetler içerisinde erkeklerle birlikte etkili olduğu bilinmektedir. Kadınlar, hem şehir hayatında hem de kırsal hayatta üzerlerine düşen sorumluluğu fazlasıyla yerine getirmişlerdir.

Çalışmamızda Başbakanlık Osmanlı Arşivi belgelerinden istifade edilerek, genel olarak Osmanlı kadınından söz edilerek, Osmanlı toplumunda Müslüman kadınların mal varlıklarını ve bu mallarını nasıl idare ettikleri, ne gibi ekonomik ilişkilere girdikleri, hangi meslekleri icra ettikleri üzerinde durulacaktır.

\section{LITERATÜR TARAMASI}

\subsection{Genel Olarak Osmanlı Kadını}

Osmanlı döneminde aileyi oluşturan en önemli unsurlardan biri kadındır. Osmanlı Devleti'nin kuruluşu döneminde kadınlar sosyal hayatın içerisinde erkeklerle birlikte daha etkin bir görüntü çizmişlerdir. Kadının ailede anne olarak yeri her zaman ön planda ve tartışılmaz bir mevkide olmuştur. Kuruluş döneminden itibaren Osmanlı'da aile temel

Geleneksel olarak Türk toplum hayatında var olan Bacıyan-ı Rum adlı kadın örgütü, Osmanlı́nın kuruluşu döneminde etkili bir tarihi rol oynamış ve toplumsal hayatın ayrılmaz bir parçası olmuştur. Anadolu Selçukluları döneminde kurulan bu teşkilatın varlığı Osmanlı devletinin 14. yüzyılın ortalarına kadar devam ettirmiştir. Kadınların üretimde ve sosyal hayatta organize olmasını sağlayan bu teşkilatın, Anadolu'daki Ahilik Teşkilatının kurucusu olan Ahi Evran'ın eşi Fatma Bacı tarafından kurulduğu tahmin edilmektedir. Türk tarihinde ilk defa Aşıkpaşazade Osmanlı Devletinin kuruluşunda rolleri olan dört önemli unsurdan bahsederken “bu Rum'da dört taife vardır: kim misafirler içinde anılır. Biri Gaziyan-ı Rum, biri Abdalan-ı Rum, biri Bacıyan-ı Rum ve diğeri ise Ahiyan-ı Rum" şeklinde dile getirmektedir (Karta, 2015) ${ }^{6}$. 
Osmanlı toplumunda geleneksel ailenin yapısı içerisinde en önemli üye kadındır. Bu durum hanedan ailesinde kendini daha bariz bir şekilde göstermektedir. Osmanlıların ilk dönemlerinde kadınların toplumsal etkinliği devam etmiştir. Bu döneminde sultanların eşleri toplumdan kopuk olarak saraylara çekilerek yaşamamışlardır. Tam tersine sultanlar gibi sosyo-politik hayatın içerisindedirler. Oldukça hür bir davranış içerisinde bulunmaları Orhan Bey'in eşi, Nilüfer Hatun'un, Kuzey Afrikalı gezgin İbn-i Battuta'ya ikram ve iltifatlar göstermesinden anlaşılmaktadır. Ayrıca Nilüfer Hatun Bursa'da bir tekke, mescit ve Bursa'dan geçen bir çay üzerine bir köprü yaptırmıştır. Sultan I. Murad'ın kızı, Melek Hatun veya Selçuk Hatun, ilk dönem Osmanlı siyasetinde yer almaktadır. Sonraki dönemlere bakıldığında Kanuni Dönemi ve sonrası Hürrem Sultan veya Mihrimah Sultan ve Esma Sultan’lar gibi padişahların hanım ve kızlarının devlet içindeki etkileri tartışılmaz derecede güçlüdür. Hatta kadınların Osmanlı sarayında nüfuz mücadeleleri bilinmektedir. Burada şuna işaret etmek gerekir. Osmanlı Devleti güçlü bir imparatorluk haline gelirken kırsal kesimde pek fazla değişme olmasa da şehirde ve saray hayatında kadının sosyal durumunda eşlerin gerisinde kalmıştır. Selçuklu döneminde kadın, İslamiyet'in benimsenmesiyle birlikte sosyal yaşantısını tümüyle yitirmemiş Türk geleneklerini korumaya çaba göstermiştir. İmparatorluğun genişlemesi, İran ve Bizans etkilerinin artması ve eski Türk geleneklerinin unutulmaya başlaması, yerleşilen coğrafyanın sahip olduğu kültürün kuşatması ve saraya giren yabancı unsurların tesirleri Osmanlı'da kadının sosyal yaşamının gitgide kısıtlanmasının nedenleri olmuştur. Kanuni dönemi ile birlikte de kadın tam anlamı ile "mahrem bir nesne" olarak görülür (Ülkütaşır,1967) ${ }^{7}$. Köylerde ve kasabalarda yaşayan kadınlar tarlada çalışıp, ev endüstrisinde ve ekonomisinde önemli rol üstlenirken, kentli kadının uğraşı evi ve evlerinin bulunduğu sokaklar ile sınırlı kalmıştır. Kentli kadının girdiği bir toplumsal olumsuzluk kadınların yaşamını sınırlayan fermanların yayınlanmasıyla, politik bir hal almıştır (Karta, 2015: 383) ${ }^{8}$.

Osmanlı toplumunda kadınların ekonomik hayata dair verimliliği (prodüktivite) erkekler tarafından kimi kez perdelense de, Osmanlı kadınlarının mülkiyet hakkına sahip olduklarından dolayı, çağdaşı pek çok kadının aksine, geleneksel aile ekonomisine katkı sağladıkları, ticari hayatta aktif olarak yer aldıkları yapılan bazı çalışmalarla ortaya konulmuştur. (Jennings, 1975; Gerber, 1980) ${ }^{9,10}$.

16. yüzyıl Osmanlı toplumunda ekonomi esas olarak tarımsal faaliyetlere dayanıyordu. Nüfusun yaklaşık olarak \%90’ kırsal alanlarda yaşamaktaydı. Bu kırsal nüfusun büyük bir bölümü devlet maliyetindeki toraklar üzerinde ve aile işletmeleri çerçevesinde tarımla uğraşmaktaydı. İşledikleri toprak miktarı ve sağladıkları gelir açısından kırsal kesim üreticileri arasında önemli bir ekonomik farklılaşma görülmüyordu. Kırsal nüfus tükettikleri giyim eşyaları ve basit üretim araçları gibi tarım dışı malların önemli bir bölümünü erkek kadın birlikte kendileri üretmekteydi. Osmanlıda nüfusun yaklaşık olarak \%10’u da kentlerde oturmakta ve esnaf loncalarına bağlı olarak zanaatlarla ve diğer tarım dışı faaliyetlerle uğraşmaktaydı (Pamuk, 1990) ${ }^{11}$. Ancak şehirlerde yaşayan kadınlar birazdan da ele alacağımız üzere esnaf loncalarına kabul edilmeksizin zor da olsa çeşitli meslekleri icra etmeyi başarmışlardır.

Osmanlı toplumunda özellikle kırsalda tarım ve hayvancılık konusunda erkek ve kadınlar arasında geleneklere dayalı bir iş bölümü olduğu açıktır (Ortaylı, 2009) ${ }^{12}$. Bu tarımsal iş bölümünde erkekler genellikle tarımsal işlerin bir kısmını yerine getirirken, kadınlar hem yeniden üretim, hem de ailenin yaşamının sürdürülmesi için gerekli tüm ihtiyaçları karşılamaya yönelik faaliyetleri de gerçekleştirmişlerdir. Bunun yanı sıra gıda seçimi, üretimi, yetiştirilmesi, hazırlanması ve hasadında da merkezi role sahip olmaları, tohumları saklayıp korumaları, hayvan üretimi ve ıslahına ilişkin bilgilere sahip olmaları nedeniyle kadınlar tarımsal üretimi geliştirdikleri gibi çeşitlenmesine de vesile olmuşlardır (Aysu, 2009) ${ }^{13}$. Dolayısıyla kırsalda kadınların hane ekonomisinde daha etkili oldukları gözlenmektedir. Devletin mali ekonomisinin temeli tımar sistemi, çift-hane üzerine kuruluydu (İnalcık, 1998) $)^{14}$. Hane evlenmiş erkeğin, eşi ve çocuklarıyla oluşturduğu küçük bir üretim birimi olarak algılanmaktaydı ve sermayesi toprak olan hane sahibi üretimin sürekliliğini sağlamak durumundaydı. Bu açıdan aile üretim açısından önemliydi.

Başbakanlık Osmanlı Arşivinde kayıtlı bulunan Tahrir defterlerinde (Başbakanlık Osmanlı Arşivi, Tahrir Defteri 149; Başbakanlık Osmanlı Arşivi, Tahrir Defteri 232) ${ }^{15,16}$ Rumeli ve Anadolu’da kadın ile ilgili olarak, bir şekilde eşini kaybeden ve bu nedenle ailenin ekonomik sorumluluklarını üstlenmek durumunda kalan "bive" olarak tabir edilen dul kadınların kayıtlarına da rastlanılmaktadır. Osmanlı şehir ve kazalarını ve buralara bağlı köyleri kapsayan, vergi vermekle mükellef reayanın kayıtlarının tutulduğu bu defterlerde kadınlar toprağı işletip vergilerini ödedikleri sürece toprakları ellerinden alınmazdı (İnalcık ve Quataert, 1994) ${ }^{17}$. 
Osmanlı Devleti tımar uygulamasında yukarıda da dile getirildiği gibi çift-hane sitemine göre vergi veren reayayı kayıt altına almıştır. Kadın ve çocukların varlığı kayıtlara yansımasa da genel kabul gören Osmanlı ailesi bir hane 5 kişiden (Barkan, 1953) ${ }^{18}$ müteşekkildir esasına göre kadın ve çocuklar da dâhil edilmiş oluyordu. Tahrir kayıtlarında adı vergiye tabi olanlar dışında doğrudan yer almasa da kadınsız bir toplum düşünülemez. Osmanlı toplumunda özellikle kırsalda kadının ekonomik katkısı düşünülenden de fazla olduğu açıktır.

Köy hayatında tarım ve hayvancılığın önemli yer teşkil etmesi, üretim bakımından kadını öne çıkarmaktadır. Burada vurgulanması gereken husus, geleneksel yöntemlerle yapılan tarım ve hayvancılık faaliyetleri içinde kadının köy hayatına entegre olmasının şehir yaşamına göre daha kolay olduğudur. Bu anlamda "kırsal alanda yasayan kadın hayatın zorluklarına daha fazla maruz kalmaktadır ve yaşam standardı şehirli kadına göre daha düşüktür" denilebilir. Ancak, şehirli kadına göre sosyal yaşamı daha özgür ve ekonomik rolü bakımından ailede konumu daha güçlüdür (Dingeç, 2010) ${ }^{19}$. Müslüman Osmanlı kadınının sosyal ve iktisadî hayatın bir parçası haline gelmesinde her hangi bir rahatsızlık söz konusu değildir. Bilhassa taşra kesimindeki kadınlar tarım, el sanatları ve atölyelerde üretime aktif olarak katılmışlardır. Dolayısıyla, Osmanlı'da kadınlar İslam Hukuku’nun kendisine sağladığı miras ve mehir alma haklarını kullanarak mal sahibi olabilme ve tasarruf etme haklarına sahiptiler. Kadın evlenmesi durumunda bu hakkını kaybetmediği gibi, evlilikte eşler arasında mal ayrılığı ilkesi olması sebebi ile kadın İslam'ın kendisine sağladığı bu haklarını da kullanabiliyordu. Osmanlı Devletinde kadın, sahip olduğu ekonomik varlığıyla çeşitli ticari anlaşmalara da taraf olmuştur (Baş, 2006) ${ }^{20}$. Kadının tam eda ehliyeti varsa (mümeyyiz, baliğ, reşit) kimsenin rızasına ihtiyaç olmaksızın malları üzerinde ivazlı-ivazsız her türlü tasarrufta bulunabilirdi (Akyılmaz, 2002) ${ }^{21}$.

\subsection{Ticari Alanda Osmanlı Kadını}

Tarihsel olarak ticaretin artması ve ticari çıkarların öncelik kazanması piyasa düzeninin kurulmasını öngörmüştür. Çeşitli kurum ve kurallardan meydana gelen bu düzen ise her toplumun kendine özgü siyasetleri, çıkar ilişkileri ve çatışmaları tarafından belirlenmiştir (İslamoğlu, 2010) ${ }^{22}$. Dolayısıyla ticaretin ve bunun piyasasını oluşturanların cinsiyeti pekte öne çıkmaz. Ancak çalışmamızda kadının ekonomik rolü hedeflendiği için pozitif bir yaklaşımla sadece kadın üzerinden hareket edilecektir.

Osmanlı toplumunda kadının ticari hayata katılması uygulamalarına bakıldığında çok sayıda örneklerle karşılaşılır. Bursa'da Emlak alımı ile ilgili kadınlar kocalarına mülk alım-satımı yapmışlardır (Gerber, 1998: 330)

23. Trabzon, Amasya, Karaman kadı sicillerinde ise yüz elli dört mülk devrinin yüzde otuz altısında kadın adına rastlanmaktadır (Baş, 2006: 69) ${ }^{24}$. Iktisadi ilişkilerde de önemli bir yeri olan borç alış verişlerinde erkeklerin olduğu kadar kadınların da yer aldığını ve bilhassa borç veren kadınların oldukça fazla olduğunu gösteren belgeler mevcuttur (Koca, 1998: 90) ${ }^{25}$. 18. yüzyıla ait belgelerde (BOA, Cevdet, Maliye, nr. 18496; Cevdet Adliye, nr. 1873; Cevdet, Maliye, nr. 21350; Cevdet, Maliye, nr. 11427; Baş, 2006) 26, 27, 28, 29, 30 iki hanımın kocalarından ev, bir hanımın babasından yirmi dokuz adet dükkân, bir kahvehane ve arsaları ile beraber zeytin ağaçlarını, iki hanımın da devletten ev satın aldıkları kayıtıdır.

Bir başka belgede de (Şer'iye Sicilleri, I ve II, Türk Dünyası Araştırmaları Vakfı, İstanbul, 1989, cilt:2; naklen Koca, 1998) ${ }^{31}$ şehirdeki mülk bahçesini Sefer kızı Fatma'ya satan Süleyman kızı Saliha'nın mülk alım-satımına ilişkin “Hacı Murat Bey mahallesinde, bir tarafı Ahmet Bey oğlu Mehmet Çelebi mülkü, bir tarafı Kasım Çavuş Bey'in mülkü ve iki tarafı da umumi yol ile sınırlı olan, su kuyusu meyveli meyvesiz ağaçları bulunan mülk bağı, bundan kısa zaman önce vefat eden kocam Malkoç Bey hayatında ve sıhhatli halinde bana şer'i ve geçerli bir bağışlama akdiyle temlik etmiş ve ben de bu bağışlamayı kabul ederek akit konusu malı teslim almıştım. Bu ana kadar tasarruf ettiğim ve vasıfları yukarıda zikredilen bağı, Hüseyin Çelebi'ye 8000 Osmanlı akçesine meşru ve geçerli bir satım akdi ile sattım ve teslim aldım. Alıc Hüseyin Çelebi de zikredildiği şekilde satın aldı, semeni olan 8 bin akçeyi de kendisinden bizzat tam olarak teslim aldım. Bundan sonra zikri geçen bağ, alıc Hüseyin Çelebi'nin mutlak mülküdür, dilediği şekilde tasarruf etsin" denilmektedir. Belgeden de anlaşılacağı üzere şehirli kadınlar mülk arazilerinin gelirlerini değerlendirmeye çalışmışlardır.

Bu açıdan kadınların mülk sahibi olabilme hakkı ve bu mülklerini tasarruf etme hürriyeti onların iktisadi hayatta iş yapabilme kabiliyetlerini geliştirmiştir. Ancak yine de şehirli kadınların işlerini vekillerine havale etmeyi tercih ettikleri görülmektedir (Koca, 1998) ${ }^{32}$. Bu tercih Osmanlı toplumunun geleneksel anlayışına bağlanabilir. Köylerde kadınları adına kayıtlı geniş mülkler, araziler söz konusu değildir. Kadınlar, Osmanlı Devleti’nin kuruluş 
dönemlerinden itibaren arz-talep çerçevesinde ekonomik girişimlerde bulunmuştur. Kırsal alanda erkeği ile birlikte tarım ve hayvancılık alanında üretime katkıda bulunurken, şehirde de imalat ve hizmet sektöründe yer almıştır. Kadın, dokuma tezgâhında çeşitli kumaşlar dokumakta, ip eğirmekte, mum imal edip satabilmekteydi (Dingeç, 2010) ${ }^{33}$.

Bir reaya ailesi, hane halkının kullanımı için üretim yapmakta, hatta devlete vergisini bile ayni olarak ödemektedir. Kadın, kırsal kesimde işgücü bakımından öne çıksa da kadınlar üzerine kayıtlı araziler sınırlıdır. Bu bakımdan kadınların alım satım işlemlerinin ekonomik etkileri konusunda genellemeler yapmak mümkün olmasa da, köy ile şehir arasında iktisadi faaliyetlerde mükemmel bir organizasyondan söz edilebilir $($ Koca,1998) 34

Müslüman kadının özellikle tüccar bir aileye mensup olması ekonomik güç elde etmesini kolaylaştırmıştır. 1600 ve 1625 yılları arasında kumaş dokuma ve deri işlemede öne çıkan Kayseri kadı sicillerinin incelenmesiyle, çok sayıda kadının toprak sahibi, üretici ve zanaatkâr olarak ekonomik faaliyet içerisinde oldukları görülmektedir (Oktar, 1998) ${ }^{35}$. Ekonomik bağımsızlığını kullanmada Müslüman kadın, İslam Hukukuna göre mal edinme ve tasarruf etme hakkı kendisinde olmasına rağmen yine de belli ölçülerde erkeklerle mücadele etmek durumunda kalmıştır. Varlık durumlarına göre dokuma tezgâhı, dükkân, değirmen, fırın işleten şehirli kadınlar kısmen kırsal kesimde yaşayan kadınlara göre daha fazla tüketici konumundadır. Kırsalda ise üretim ve tüketimin temelini oluşturan aile önceden de ifade edildiği gibi hane emek birimine dayanmaktadır. Aile içerisinde erkek kadın ayrımı olmaksızın mal ve üretim ortaklaşa yapılmaktaydı. 1567'de Arazi Kanunnamesinde yapılan bir düzenleme ile toprağın tapu bedeli erkek çocuklarda olduğu gibi kız çocuklarına da geçmesi sağlanmıştır $(O k t a r, 1998){ }^{36}$. Böylece kırsalda kadın miras hakkını da elde ederek üretime tarlasında, bağında çalışarak katılmaktadır (Altındal, 1994) ${ }^{37}$.

Osmanlı Devleti'nin ilk dönemlerinden itibaren şehir hayatında ticaret ve küçük çapta sanayiye dayalı olarak kadınlar eliyle üretim kollarının varlığı söz konusudur. Osmanlı kadınları vakıflardan dükkân kiraladıkları gibi mülkiyeti devlete ait olan çiftliklere ve devletin gelirleri arasında yer alan mukataaları iltizam yolu ile bazen malikâne divanı uygulaması yöntemi ile tasarruf hakkını elde ederek sahip oldukları mal varlıklarıyla yatırım yapmış ve kendilerine yeni gelir kaynakları elde etmişlerdir. Konuya ilişkin birkaç örnek vermek gerekirse; İstanbul Şeriyye sicili kayıtlarında (işS. Bab Mahkemesi, nr. 135, vr. 68b.1) ${ }^{38}$ "Dülbentci Hüsam mahallesinde, Emetullah Hatun vakfından icareteyn ile karısı Meryem'in tasarrufunda olan vakıf menzilin, tamamen yandı̆̆ını ve karısının isteğiyle, kendine ait parayla, yeniden bina ettirdiğini” belirtmektedir. Başka bir belge de ise; (BOA, Hatt-ı Humayun, nr. 15962) ${ }^{39}$ vefat eden mumcular kethüdâsı Hacı Hüseyin'in Tekfur Sarayı ve sâir mahallerde olan mumhâne gediklerini irsen eşi Naile hanıma geçmiştir Diğer bir belgede de (BOA, Cevdet, Evkaf, nr. 2173)

40 Haftan Ağası'nın eşi Hafize Hâtun, Büyük Ayasofya Vakfı'ndan üç yumurtacı dükkânı hissesine mutasarrıftır. Hafize Hanım hac yolculuğunda vefat edince yumurtacı dükkânı hisseleri yedi yüz kuruşa açık arttırma ile talibine kiralanmıştır. Osmanlı kadınlarının yukarıdaki örneklerden anlaşılacağı üzere benzeri kazanç sağlayan birçok işletmeye sahip olduklarını göstermektedir.

15. yüzyılın başlarında Osmanlı'da ipekçilik ve buna dayalı olarak dokumacılık ile öne çıkan ve ekonomik faaliyetlerin yoğun yaşandığı Bursa'da ticari faaliyette bulunan Araplar, İstanbul Yahudileri ve yerel tüccarlardan da bahsedilecek olunursa, bu dönemde Bursa ticaretinin boyutu Karadeniz ticareti de dâhil olmak üzere İtalyan tüccarlarının elinden alınarak Osmanlı uyruklarının eline geçti ve 1450 ile 1480'li yıllar arasında ipekli dokumacılık alabildiğine genişledi (Faraqhı, 2008) ${ }^{41}$. Bu dönemde iş imkânlarının artması ve Osmanlı tebaası olmayan yabancı kimselerin de çalışmak için Bursa'ya göç ettikleri görülmektedir. XVI. Yüzyılın başlarında Osmanlı Devleti Akdeniz ülkeleriyle birlikte nüfus artışlarına sahne olmuş ve 1520-1580 arasında bu nüfus artışı şehirlerdeki üretim artışını da beraberinde getirmiştir (Koca, 1998) ${ }^{42}$. Bu yönüyle Bursa, Yabancı tacirlerin cazibe merkezi konumuna sahip olurken, öte yandan da ipek dokumacılığı ve ticarette de önemli bir yere erişmiştir (Özbay, 2009: 149-150) ${ }^{43}$. Bursa ipek sanayiinin hammadde açısından dışa olan bağımlılığı, siyasi olaylara da yön vermiştir. Nitekim Sultan I. Selim ile Safevi hükümdarı Şah İsmail arasında süren siyasi çekişmeler 1514'te ticareti durdurmuş ve çıkarılan bir ferman aracılığı ile 1518'de ise İran ipeği yasaklanmıştır (Faraqhı, 2008) ${ }^{44}$. Bunun üzerine kozacılık önem kazanmıştır. Kozadan başlayarak, ipliğin çekilmesi, bükülmesi, boyanması, ibrişim olarak işlenmesi, satışı ve dokunması dâhil her aşamada çok sayıda kadın emeği kullanılmıştır (Oktar, 1998) ${ }^{45}$. 
Osmanlı kadını İstiglâl ${ }^{1}$ ve Mudârabe ${ }^{2}$ yöntemini de kullanmıştır. Osmanlı'da kadınlar zaman zaman vakıflardan ve şahıslardan gayrı menkûllerine karşılık istiglâl yöntemi ile kredi almışlar ve daha sonra borçlarını ödeyerek gayrı menkûllerini geri almışlardır. Öte yandan mudârabe yöntemi ile bir miktar parası olan kadınlar bazen paralarını bir ortağa verip işletiyorlardı. 16. Yüzyılda Osmanlı Devleti'nde şehirler ticaret ve hizmete dayalı olarak emeğin yoğun olduğu merkezlerdi. Dolayısıyla erkekler kadar kadınların da şehirlerin sosyal ve ekonomik hayatında aktif oldukları görülmektedir. Özellikle kendi ürettiklerini pazarlarda yine kendileri satarak ihtiyacı olanı satın almaları ile ekonomik hayata canlııı katmışlardır.

\subsection{Iş Gücü Köle Kadın (Cariye)}

Ekonomik faaliyetler içerisinde yer alan menkul ve nakitten sonra emek gücünü oluşturan köle kadınlardı. Köle ve cariyeler alınıp satılabildiği gibi aynı zamanda miras da bırakılabilmekteydi. Böylece bu statüdeki kadın önemli bir yatııım aracı haline geliyordu (Sahillioğlu, 1981) ${ }^{46}$. İpek dokumacılığının yaygın olduğu Bursa'da, ipek ipliği eğirmede ve ipekli dokumada işgücünü Müslüman kadınlar ile köle kadınlar oluşturmaktaydı (Inalcık,1993) 47. Örneğin; Bursa'da yedi dokuma tezgâhına sahip Hacı Bedrettin İhsan'ın sekiz kadın kölesi vardı. Kadın emeğinin önemli bir yönü de kasabalarda ve bazı köylerde keten dokumacılığı ile de öne çıkmaktadır (İnalcık, $1985)^{48}$. 15. Yüzyılın ortalarında Hacı Sinan isimli şahsın 6 dokuma tezgâhı, 20 erkek ve 3 kadın köle çalıştırdığı görülmektedir. Bir başka belgede de 1500'lü yıllarda 1000 kadar ipekli dokuma tezgâhı sahibi kadınlara ait iken, 1530 ve 1544 tarihlerinde ibrişim büken, 1574'te ise vale (bir cins ipekli kumaş) ustası kadınların adlarına rastlanmaktadır. (Dalsar, 1960; Oktar, 1998) ${ }^{49,50}$. Dokumacılık yapan erkeklerden başka, bedenen çalışan kadın dokumacılar da vardı. İşi dokumacılık olan ve devamlı bu meslekle uğraşanların yanında, işi farklı olmasına rağmen ihtiyaca göre köleleriyle mükâtebe ${ }^{3}$ yaparak, kumaş dokutanlar da bulunmaktaydı (Sahillioğlu, 1981) ${ }^{51}$. Anlaşmalı azatlık demek olan mükâtebe genellikle kölelerin sadakatle hizmetini sağlamağa yönelikti (Sahillioğlu, 1981) ${ }^{52}$.

Osmanlı arşiv vesikalarında tespit edilen bir belgeye göre terekesinde köle bulunan tek hanım Rûhi Süleyman Ağa'nın eşi Emetullah Hanım'dır. Emetullah Hanım'ın ikisi bâkire üç Çerkez câriyesi vardır. Câriyelerin toplam bedeli 3870 kuruştur (Baş, 2006: 75) ${ }^{50}$. Terekeler ile ilgili yapılan bir çalışmada cariye sahibi erkeklerin yanı sıra 2 Müslüman kadının da köle sahibi olduğu tespit edilmiştir. (Öztürk, 1994) ${ }^{53}$ Osmanlı Devleti’nde kölelik, genel itibariyle ev hizmetlerinde çalıştırılmak şeklinde yaygındı.

Ancak kölelik, imalathane sahipleri için ekonomik bir değer olarak görülmüştür. Kadın köleler, söz konusu olduğunda cariye olarak nitelendirilmişlerdir. Yukarıda da dile getirildiği gibi Mükâtebe uygulaması ticari anlayışa uygun olduğu bir zamanda köle sahibinin kölesi ile anlaşma yapmak, hem yatırımını değerlendirmek, hem de devamlı teşvik edilen azatlık için iyi bir yoldu. Kölenin beklediği ise, özgürlüğüne bir an önce kavuşmaktı. Anlaştığı işi bitirdiği takdirde özgürlüğüne kavuşuyordu (Özbay, 2009) ${ }^{54}$.

Osmanlı Kadınının miras aldığı, miras bıraktığı, borç aldığı, borç verdiği, emlâk alıp sattığı, vakıf kurduğu ve yönettiği yukarıdaki açıklamalardan anlaşılmaktadır. Osmanlı kadınının hem şehirlerde ve hem de kırsalda kadın hastalıklarını tedavi etme, doğum yaptırma ve benzeri meslekleri icra ettiği de görülmektedir. Ev işlerini yapmak ve çocukların eğitimiyle ilgilenmek de Osmanlı kadınının ana sorumlulukları arasındadır. Bu açıdan bakıldığında Osmanlı kadınının devletin kurulduğu andan itibaren ekonomik rolü tartışma götürmez (Dulum, 2006) ${ }^{55}$.

\subsection{7. ve 18. Yüzyılda Osmanlı Kadının Ekonomik Faaliyetleri}

17.yüzyıla gelindiğinde Müslüman kadınların ekonomik alanda etkinliğinin meslek ve hizmet bakımında arttığı görülmektedir. Şehirde yaşayan kadınların, her ne kadar memur statüsünde bir konuma sahip olmasalar da, aile mirası olan gayrimenkulün işletmeciliğini üstlenmek suretiyle ekonomiye katkı sağladıkları daha önce de dile getirilmişti.

1 Emlâk ve akarı borcuna karşılık alacaklıya bırakmak yahut gayrı menkûlün adını borca karşı terk ve tahsîs etmek.

2 Bir taraftan sermaye diğer taraftan emek ve çalışma üzerine kurulan bir ortaklık çeşidi.

3Anlaşmalı olarak işi tamamladığında azâd edilmek üzere bir bedele bağlanan köle. 
Bu devirde kadınlar, 1240'da Anadolu'da faaliyet gösteren "ahilik" ve 1727'de "gedik" adını alan esnaf ve sanatkâr kuruluşlarının (Gürol, 2000) ${ }^{56}$ bir parçası olmasalar da evde imal ettiği ürününü, aracıya ihtiyaç duymadan çarşı-pazarlarda satabilmişlerdir. Şehir ve kırsal alanda bulunan "Avrat pazarı" olarak isim yapan bu alışveriş yerleri, sebze ve meyve gibi tarımsal ürünlerin yanında hayvansal ürünleri ve kadınların kendi yaptıkları el işlerinin satışa sunulduğu yerlerdi. Hürrem Sultan'ın desteği ile kurulan Haseki Darüşşifa ve İmaretinin yakınlarında bulunan söz konusu pazar en yoğun olanı idi. Kadınlar burada hem alııı hem de satıcılardı (Dingeç, 2010) ${ }^{57}$. Osmanlı kadınını tasvir etmek bakımından önemli bir gösterge de servet sahibi Müslüman kadınların terekelerinde menkûl, gayrı menkûl mallarının dökümünde kullandığı ev eşyasından ziynet eşyasına kadar her şey kayıt altına alınmıştır. Bu kayıtlar arasında okudukları kitaplar da bulunmaktadır. Osmanlı kadınlarının bilhassa ümera (yönetici) sınıf veya saray mensuplarının eşlerinin kitap okudukları anlaşılmaktadır. Örneğin, Rûhi Süleyman Ağa'nın zevcesi Emetullah Hanım'ın terekesinde Kur'an-ı Kerim bulunmakla beraber, Yâsin Tefsiri, Falnâme, İnşâ, Dîvân, Eflak-Şems ve Kamer adlı bir kitap, Şahnâme, Tabirnâme, Bâkî Dîvânı, Delâil-i Şerîf, Enâm-ı Şerîf ve bir dîvân ile birlikte on üç kitabın adı kayıtıdır. Bu kitapların maddi değeri 11.089 kuruştu (Baş, 2006) ${ }^{58}$.

Osmanlı toplumunda kadınlar daima üretim ve ticaretin içinde bulunurken, arz ve talep durumuna göre bilhassa şehirli kadınların ürettikleri gibi tüketime de önem vermişlerdir. Özellikle saraylı kadınların üretimden çok tüketime yöneldikleri gözlenmektedir. İhtiyaç duydukları malları bohçacı olarak tabir edilen kadınlar eliyle sağlarlardı. Bohçacı kadınlar, mahallelerde kapı kabı dolaşarak yatak, çarşaf, çeşitli kumaşlar, incik boncuk satarlardı. Kadın olmaları nedeniyle rahatlıkla hareme girer, hanım ve cariyelere satış yaparlardı (Tokmakçıoğlu, 1991) ${ }^{59}$. Osmanlı kadınları hiç kısıtlı bir hayat içerisinde değillerdir. Elizabeth Cooper bu konuda; "Kadınların kelimenin hiçbir manasında tutsak olmadıkları gibi, kimi zaman bazı kişilerin bizi inandırmak istediklerinin tersine, kafesli pencerelerin ardından çıkmak için can atıyor da değillerdir. Bu mahremiyet hali Müslüman kadına ağır gelmez, hatta mahremiyetinin bozulması herkesten önce onu kızdıracaktır, çünkü böyle bir şey onun kocasının gözündeki kıymetini kaybettiği anlamına gelir" diyerek Osmanlı kadının ciddiyetini ve hassasiyetini tanımlamaktadır (Sancar, 2010) ${ }^{60}$.

Muhtemelen Osmanlı haremi üzerine yazılar kaleme alan yabancı seyyahların bohçacı kadınların dile getirdiklerinden yola çıkarak harem hakkında bir takım tanımlamalar ortaya koymuş olmalıdırlar.

Burada altı çizilmesi gereken, Osmanlı toplumunda şehirli olsun kırsalda yaşayan kadın olsun her şeyi ile mükemmeldi denilemez. Çünkü kırsalda kadın ailesi ile birlikte bağ-bahçe, tarım ve hayvancılıkla ilgili bedenen çalışırken, şehirlerde yaşayan ve evine bakmak zorunda kalan bir kadın için hayat zordu. İş bulabileceği alan genelde ev hizmetçiliğiydi. Ev hizmetçiliğinde ise insan kaynağı genellikle kölelerden sağlanmaktaydı. Özgür ana-babanın çocuklarının köleleştirilmeleri yasak olduğundan Osmanlı tebaasından bir kadının iş bulması da zorlaşıyordu. Kadınlar, Osmanlı iş piyasasında yeterli iş olmaması veya istediği şartlarda kendine uygun çalışma bulmadığı zamanlarda da işsiz kalmakta idi. İş buluncaya kadar bazı kadınların ihtiyaçları vakıflar eliyle giderilmekte idi. Ancak burada iş ihtiyacı olan veya muhtaç durumdaki kadınların tümünün vakıflar eliyle ihtiyaçlarının karşılandığı söylenemez. Kimi kadınların Çukurova'da, Ege ve Akdeniz'de tarım işçisi olarak çalıştıkları görülmektedir (Dulum, 2006) ${ }^{61}$.

\subsection{Tanzimat ve Sonrasında Kadın}

19. Yüzyılda Batı'da Sanayi devrimi ile hizmet sektörü çeşitlendi ve hizmet sektörüne ekonomik bir değer kazandırdı. Osmanlı devletinin ilk yıllarında kadınların zaviyelerde gelip gidenlere hizmet ettiklerini kolayca tespit edebiliyoruz. Ahi tekke ve zaviyelerinde misafir olarak barınanları kadınlar ağırlamışlardır. Nitekim döneme ilişkin kayıtlar Kız Bacı, Ahi Ana, Sakari Hatun, Hacı Fatma gibi zaviye adlarının kadın adları ile anılması ve kadınların bu gibi yerlerde hizmet sunduklarını göstermektedir (Koca, 1998) ${ }^{62}$.

Sanayileşme çabaları ve yeni iş imkânlarının ortaya çıkmasıyla birlikte çalışan kadınların toplumdan beklentileri ve ihtiyaçları arttı. Tanzimat ve II. Meşrutiyet dönemlerinde de bu ihtiyaçlarının karşılanması daha somut beklenti ve çabalara dönüşmüştür. Daha önceden geleneksel olarak her hangi bir eğitim almadan ampirik yöntemlerle yapılan mesleklerden söz edilmişti. Bu dönemde de kurumsal olarak kızların ebe ve öğretmenlik mesleklerine yönlendirilmesine çalışılmıştır. İki yıllık bir eğitimden sonra 1845'de 36 kadından 10 Müslüman 
kadın ebelik diploması almıştır. Kadınların ücretli iş̧̧i olarak çalışmaya başlamaları daha öncede ifade edildiği üzere sanayi devrimin doğmasıyla başlar ve toplum hayatında belirgin hale gelir (Oktar, 1998) ${ }^{63}$.

19. yüzyılın ilk yarısında itibaren Osmanlı sanayisinde yaşanan gelişmeler Müslüman kadınların ekonomik faaliyetlerini yakından etkilemiştir. Anadolu'da ve Rumeli şehirlerinde ve kırsalında kadınlar ev tezgâhlarında gömlek dokurlardı. Hatta büyük şehirlerin kibar konaklarına tezgâhlar konup kız ve hanımları gömlek, don, çarşaf dokutmak için yevmiye ile çalıştırırlardı. Bez, gömlek, don, takye, çarşaf, çorap, mintan, yaygı perde gibi melbûsat ve mefrûşat böylece dış ülkelerden ithal edilmezdi. Genelde ihtiyaç duyulan ürünler evlerdeki yahut çarşıdaki tezgâhlarda dokunur ve çoğu kez kadınlar kendileri satar, evin bütün ihtiyaçlarını gidermek üzere erkeğine yardımcı olurdu (Özbilgen, 2010) ${ }^{64}$. Bazen de kadınlar tarafından dokunan kumaşlar Osmanlı Devleti'nin hemen her tarafında çullah esnafları tarafından bezastan denilen mekânlarda satılırdı (Koca, 1998) 65

19. yüzyılın ikinci yarısından itibaren başta İngiliz olmak üzere Batı teknolojisi ve sermayesinin Osmanlıya akmaya başlaması ile birlikte kadınlar kent merkezlerinde gelişen ekonomik hayat içinde yer almaya başlamışlardı. Özellikle tekstil alanındaki üretim büyük ölçüde kadın emeğine bağlı olarak gelişmekteydi. Kadın hareketinin kökleşme dönemi olarak nitelendirilebilecek bu dönemde kadınların henüz politik bir kimlik kazanmadığı sadece yeni gelişen kamusal alanda ekonomik hayata katılmak istedikleri söylenebilir. Bununla birlikte gelişmekte olan Osmanlı sanayisinin ihtiyaç hissettiği alanlarda gelişen eğitim kurumlarında da kadınların eğitim alma imkânına kavuştuğu, dolayısıyla "kültürlü" kadın kuşağının özellikle 19. Yüzyılın ikinci yarısından itibaren artmaya başladığı söylenebilir (Karta, 2015) ${ }^{66}$.

Bu dönemde Anadolu'nun birçok şehrinde evde yün dokuyan kadın sayısı toplam sekiz bine yaklaşıyordu. İzmir'deki el tezgâhlarında 3.500 kadın, 750 kız çocuğu halı dokuyordu $(O k t a r, 1988){ }^{67}$. 19. Yüzyılın ortalarından itibaren elişleriyle ilgilenen, dokuma tezgâhlarının başında oturan kadınlar, artık fabrika işçisi sıfatıyla ekonomik faaliyete katıldılar. Yüzyılın sonlarına doğru Osmanlı Devleti’nde iplik eğirilen birkaç fabrika kuruldu. Ucuz kadın emeğinden yararlanan bu Osmanlı fabrikaları İngiltere, Belçika ve İtalya ve Hindistan üreticileriyle rekabet etme başarısını göstermiştir. 1850'de ve sonrası süreçlerde Osmanlı sanayileşmesinde önemli bir girişim olarak kabul edilen Bursa İpek Fabrikası da kapılarını kadınlara da açınca bu fabrikalarda çalışan kadın işçi sayısında önemli bir artış olmuştur (Quataert ve Zürcher,1998) ${ }^{68}$.

Zamanla meydana gelen sosyal şartlar Osmanlı kadınını farklı çalışma alanlarına da itmiştir. Karşılaşılan bazı özel durumlar nedeniyle Osmanlı yönetimi kadın eleman çalıştırma yönünde yeni bir uygulama yapmak zorunda kalmıştır. Örneğin, hükümet tarafından sürgün cezasına çarptırılan kadın mahkûmlara sürgün yerlerine götürülene kadar eşlik etmeleri maksadıyla "Kadın Çavuş"lar vazifelendirilmiştir. Yine benzer bir örnekte "Trabzon Rûsumat Nezareti”ne yapılan bir ihbarda Osmanlı vapurunda yolculuk yapan dört kadının özel eşyaları arasında tabanca ve çeşitli miktarlarda kurşunların bulunduğu tespit edilmiştir. Bu ihbar üzerine yetkili makamlar, bu duruma sebep olan kadınların üzerinin kolcular tarafından aranmaması olarak gösterilince "bir kadın kolcunun gümrüğe atanması ivedilikle" istenmiştir. Bunun üzerine Padişah İradesi çıkmış ve Trabzon Gümrüğü'ne bir "Kadın Kolcu” atanmıştır. Bu görevliye aylık 250 kuruş maaş verilmek üzere üç bin kuruş bütçeye tahsisat ayrılmıştır (Oktar, 1998) ${ }^{69}$. Muhtemelen, ilk kez bu uygulama ile bir Müslüman kadın Osmanlı idaresinde resmi görevli olarak atanmıştır.

\subsection{Meşrutiyet Döneminde Kadın}

II. Meşrutiyet döneminde Osmanlı Devleti'nin yoğun olarak yaşadığı savaşların etkisiyle ekonomik sorunlar ve yabancılara daha önceki dönemlerde kapitülasyonlar ile sağlanan kolaylıklar zamanla Osmanlı Devleti'ni dışarıya bağımlı hale getirmişti. Bu bağımlılığa karşı milli iktisat olarak da ifade edilen ekonomik anlayış gazete, dergi ve kitaplarda sık sık yer almakta idi. Kadınlar da konu ile ilgili düşüncelerini hem yönetici hem de yazar olarak yayınladıkları Kadınlar Dünyası Dergisi ile toplumu aydınlatmaya çalışmışlardır. Uzun süren savaşlar ekonomik maliyetleri oldukça artırmış ve iş gücü açığı ortaya çıkmıştı. Amaç, ülke ekonomisini canlandırmak için kadınların bu açığı kapatması ve aynı zamanda iş hayatına dâhil olmalarıydı ( Dulum, 2006) ${ }^{70 .}$

II. Meşrutiyet Döneminde eğitim seviyesinin yükselmesi, dönemin aydınlarının kadın hareketlerine verdiği destek ve zamanla sağlanan ortamlar kadınların daha aktif olmasını ve çeşitli iş kollarında yer almasını sağladı. Osmanlı kadını sanayi iş̧̧isi olarak da önemli bir işleve sahipti. 1897 yılında İstanbul'daki kibrit fabrikasında 
çalışan 201 iş̧̧inin 121'i kadındı. Bakırköy bez fabrikasında çalışanların yarısını kadınlar oluşturuyordu (Gürol, 2000) ${ }^{71}$.

1917 'de yapılan bir istatistiğe göre resmi dairelerde, ticarethanelerde ve çeşitli hizmetler veren özel işletmelerde çalışan kadın sayısı 1000'e yaklaşmıştı.1913 ve 1915 yıllarında ilk kez yapılan sanayi sayımlarında, işçi statüsünde çalışanların 1/3'ünü kadınların oluşturduğu tespit edilmiştir (Aydın, 1999) ${ }^{72}$.

1918'de İstanbul Postanesi'nde çalışan Müslüman kadın sayısı 852'ye ulaşmıştı. Ancak Savaş yıllarında erkeklerini cepheye yollayan kadınların yaşam koşulları her geçen gün daha da zorlaşıyordu. Müslüman kadınların karşı karşıya kaldığı ekonomik sıkıntılardan büyük rahatsızlık duyan Harbiye Nazııı Enver Paşa, bazı toplumsal önlemler alma ihtiyacı hissetmiş olacak ki; "Kadınları Çalıştırma Cemiyet-i İslamiyesi”ni kurdu (BOA, Dahiliye Nezareti Kalem-i Mahsus Evrakı, Dosya No: 42 Gömlek No: 10) ${ }^{73}$. Bu cemiyet Eşi Naciye Sultan'ın himayesi altında merkezi i̇stanbul'da olmak üzere çeşitli şehirlerde şubelerini açarak önemli faaliyetlerde bulundu. Kadınların çoğunlukla iş sahibi olduğu ve kazanç elde ettiği alanlar, dokuma ve gıda sektörüydü. Kadın derneklerinin desteği ile biçki ve dikiş çıraklık merkezleri faaliyete geçmesiyle meslek edinen kadınlar, konfeksiyon atölyelerinde kolayca iş bulabiliyor, özellikle göç eden Rum ve Ermeni kadın işçinin yerine işe giriyorlardı. Bu dönemde faaliyet alanı genişleten "Kadınları Çalışırma Cemiyet-i İslamiyesi" bir iş ve iş̧i bulma kurumuna dönüştü. ihtiyaçlar yoğunlaşınca Meclis-i Vükelâ’nın kararı ile çeşitli kuruluşlarda istihdam edilmek üzere mağdur olan yetim ve dul kadınlara da iş bulma imkânı sağlanmıştır.

Osmanlı'da kadınlar, maden işçisi olarak da çalışmıştır. 1915 yılı sanayi sayımı sonuçlarına göre, çeşitli sektörlerde kadın iş̧̧ilere ödenen gündelikler, erkek iş̧̧ilere ödenenlerin yarısı kadardır. Kadınlar daha çok öğretmenlik, hemşirelik gibi mesleklerde yoğunlaşmışlardır (Doğramacı, 1997) ${ }^{74}$. Yukarıda da ifade edildiği gibi, en eski mesleklerden biride ebelikti. Osmanlı toplumunda genel olarak doğumlar evlerde ampirik bilgi ve deneyimlere sahip kadınların yardımıyla yapılmaktaydı. Ebeler pek çok doğumda bulunduklarından bazı manipülasyon tekniklerine sahiptirler. Ebelik hizmetleri yanında lohusalıkla ilgili koca karı ilaçları da düzenlerler. Osmanlı toplumunda ebelik mesleğinin tıbbi bir görünüm kazanması ancak 1827 de açılan "Tıphâne-i Âmire" de verilen cerrahiye dersleri içinde ele alındı. 1848 yılında da ruhsat nameli ebeler mezun edildi (Özbilgen, 2010) 75 .

Osmanlı'nın ekonomik yaşamında kadınların toplumda îfâ ettiği bazı meslekler, kadınlara hem gelir sağlamış hem de toplumsal hayatın aktif özneleri olmalarına imkân vermiştir. Açıkça belirtmek gerekirse, Osmanlı toplumunda kadın belli sektörlerde ağırlıkı olmak kaydıyla sanılanın ötesinde girişimci ve üretici olarak ekonomik hayatın her alanında yeri almıştır.

\section{SONUÇ}

Osmanlı toplumunda nüfusunun takriben \%90'ı kırsalda yaşamaktadır. Bu bakımdan ekonomik hayat kırsalda büyük ölçüde tarım ve hayvancılığa dayanmakta idi. Kırsalda erkeklerle birlikte aktif rol üstlenen kadınlar, ailenin mali ihtiyaçlarına katkıda bulunacak çeşitli faaliyetlerde bulunuyorlardı. Bu ekonomik faaliyetler gündelik ev işleri yanında küçük çapta dokuma, boyama, bağ-bahçe işleri, tohum saklama ve üretimi geliştirmeye yönelikti. Şehirde yaşayan kadınların ise ebelik, ürettikleri malları pazarda satma, dükkân ve çamaşırhane işletme gibi faaliyetlerin yanı sıra; köle ticareti, vakıf yöneticiliği, gayrimenkul alım-satımı gibi iktisadi faaliyetlerle de iştigal ettikleri Başbakanlık Osmanlı Arşivinde yer alan vesikalardan tespit edilebilmektedir.

17. yüzyıl tereke defterleri üzerinde yapılan incelemeler, şehirlerde kadınların üçte birinin ev sahibi olduğunu göstermiştir. Şehirlerde atölye sahibi hanımlara rastlanmıştır. Bursa ipekli sanayiinde üretim yapan tezgâhlardan üçte birinden fazlası kadınlara aittir. Her ne kadar loncalara üye olmasalar da, kadınlar bilhassa tekstil alanında ürettikleri ürünlerini çarşı ve pazarlarda satarak ticaret faaliyetinde bulunmuşlardır. Kadınların tereke defterlerinde görülen mal varlıkları kendilerine gelir getirecek ekonomik bir faaliyette bulunduklarının göstermektedir. Osmanlı ekonomisinde "mudarebe" diye bilinen, ticarette belli bir oranda kâr alma esasi üzerine, sermaye vererek ticarî ortak olan kadınlara da rastlanmıştır.

Osmanlı Devleti'nde mükatebe yöntemi ile köle kadınların çalışıııılığı tespit edilmektedir. Kölelik, genel itibariyle ev hizmetlerinde çalıştııımak şeklinde yaygındı. 
Osmanlı toplumunda tarım sektörünün dışında, bilhassa şehirde yaşayan ve mali imkânlara sahip olan kadın, miras aldığı, miras bıraktığı, borç aldığı, borç verdiği, emlâk alıp sattığı, vakıf kurduğu ve yönettiği görülmektedir. Osmanlı kadııını hem şehirlerde ve hem de kırsalda kadın hastalıklarını tedavi etme, doğum yaptırma ve benzeri meslekleri icra ettiği de görülmektedir. Ev işlerini yapmak ve çocukların eğitimiyle ilgilenmek de Osmanlı kadınının ana sorumlulukları arasındadır. Meşrutiyet döneminde Türk kadını, siyasi gelişmelere paralel olarak yardım toplama faaliyetleri içerisinde bulunması yanı sıra çalışma hayatına katılması ile de kendini göstermiştir. Bu açıdan bakıldığında, Osmanlı kadınının devletin kurulduğu andan itibaren ekonomik hayat içinde aktif olarak rol aldığı görülmektedir.

\section{KAYNAKÇA}

Akyılmaz, G. (2002), Osmanlı Aile Hukukunda Kadın, Türkler, Yeni Türkiye Yayınları, C.10, Ankara, 365-374, (21) p. 368.

Altındal, M. (1994), Osmanlıda Kadın, Altın Kitaplar Yayınevi, İstanbul, (37) p. 50.

Aydın, M. O. (1999), "Yasal Açıdan Kadın İşücü,” Türkiye’de Kadın İşgücü Seminerleri, 1-2, TísK Yayınları, Yay. No. 192, (72) p. 73.

Aysu, A. (2009), Piyasa ve Küçük Köylülük. Mülkiye Dergisi, Bahar, (13) p. 223-237.

Barkan, Ö.L.(1953), “Tarihi Demografi Araştırmaları ve Osmanlı Tarihi”. Türkiyat Mecmuası X, (18) p. 1-26.

Baş, E. (2006), Arşiv Belgelerinden Hareketle XVIII. Y. Y. Osmanlı Toplum Hayatında Kadın, Marmara Üniversitesi, Sosyal Bilimler Enstitüsü, Yüksek Lisans Tezi, İstanbul, (2) p. 67, (20) p. 6, (24) p. 69, (30), (51) p.75, (58) p. 81.

Başbakanlık Osmanlı Arşivi, Cevdet, Adliye, nr. 1873, (27).

Başbakanlık Osmanlı Arşivi, Cevdet, Evkaf, nr. 2173. (40).

Başbakanlık Osmanlı Arşivi, Cevdet, Maliye, nr. 11427 (29).

Başbakanlık Osmanlı Arşivi, Cevdet, Maliye, nr. 18496, (26).

Başbakanlık Osmanlı Arşivi, Cevdet, Maliye, nr. 21350, (28).

Başbakanlık Osmanlı Arşivi, Dahiliye Nezareti Kalem-i Mahsus Evrakı, Dosya No: 42 Gömlek No: 10. (73).

Başbakanlık Osmanlı Arşivi, Hatt-ı Humayun, nr. 15962, (39).

Başbakanlık Osmanlı Arşivi, Hatt-ı Hümâyûn, nr. 14853. (76)

Başbakanlık Osmanlı Arşivi. Tahrir Defterleri. 149 (15) p. 257-342.

Başbakanlık Osmanlı Arşivi. Tahrir Defterleri.232 (16) p. 287-383.

Dalsar, F. (1960), Türk Sanayi ve Ticaret Tarihinde Bursa'da İpekçilik, İstanbul Üniversitesi İktisat Fakültesi Yayınları, No.116, İstanbul, (49) p. 396.

Dingeç, E. (2010), Osmanlı Toplumunda Kadınların Üretime Katkıları, History Studies, 2/1, 9-30. (19) p. 18, (33) p. 17, (57) p. 13.

Doğramacı, E. (1997), Türkiye'de Kadının Dünü ve Bugünü, Türkiye İş Bankası Yayınları. No.300, Sosyal Felsefi Dizi:31, Doğuş Matbaacılık, Ankara, (74) p. 21.

Dulum, S. (2006), Osmanlı Devleti’nde Kadının Statüsü, Eğitimi ve Çalışma Hayatı (1839-1918), Osmangazi Üniversitesi, Sosyal Bilimler Enstitüsü, Yüksek Lisans Tezi, Eskişehir, (55) p. 55, (61) p. 56, (70) p. 60.

Ecer, V.A. (2012), Tarihte Lider Kadınlar ve Fatma Bacı, İstanbul, (3).

Faraqhi, S. (2008), Osmanlı Dünyasında Üretmek, Pazarlamak, Yaşamak, YKY, İstanbul, (41) p. 103, (44) p. 104.

Gerber, H. (1980), “Social and Economic Position of Women in the an Otoman City, Bursa, 1600-1700”, IJMES, cilt 12, (10) p. 231-244.

Gerber, H. (1998), "Bir Osmanlı Şehri Olan Bursa'da Kadının Sosyo-Ekonomik Statüsü (1600-1700)”, çev. Hayri Erten, Selçuk Üniversitesi Ilahiyat Fakültesi Dergisi, (sayı:8), 327-343, (23) p. 330.

Gürol, M. A.(2000), Türkiye' de Kadın Girişimci ve Küçük İşletmesi. Atılım Üniversitesi Yayını, Ankara, (56) p.246, (71) p. 246.

İnalcık, H. (1985), Servile Labor Studies The Ottoman Social And Economic History,Rice Cultivation in the Ottoman Empire, London. (48) p. 27-29.

İnalcık, H. (1993), "Bursa: XVI. Asır Sanayi ve Ticari Tarihine Dair Vesikalar", Osmanlı İmparatorluğu Toplum ve Ekonomi, Eren Yayınları, İstanbul, (47) p. 45.

İnalcık, H. (1998), " Çiftliklerin Doğuşu: Devlet Toprak Sahipleri ve Kiracılar", Osmanlı'da Toprak Mülkiyeti ve Ticari Tarım, ed. Çağlar Keyder, 
Faruk Tabak, Tarih Vakfı Yurt Yayınları, İstanbul, (14) p.17-35

İnalcık, H. ve D. Quataert, (1994),An Economic and Social History of the Ottoman Empire 1300-1600, C.1, Cambridge University Press, Cambridge, (17) p. 148.

İslamoğlu, H. (2010). Osmanlı İmparatorluğu'nda Devlet ve Köylü, İletişim Yayınları, İstanbul, (22) p. 62.

İstanbul Şeriye Sicili; işS. Bab Mahkemesi, nr. 135, vr. 68b.1, (38).

Jennings, R. C. (1975), "Women in Early17th Century Otoman Judicial Records-The Sharia Court Of Anatolian Kayseri" , Journal of the Economic And Social History Of The Orient, Vol: XVIII, Part:1January, (9) p. 53-114.

Karta, N. (2015), “ilk Çağlardan Günümüze Kadının Konumu”, Dünyada, Türkiye’de Kadın ve Şiddet, Nobel yayınları, Ankara, (6) p. 382-383, (8) p. 383, (66) p. 392.

Koca, K.Y. (1998), Osmanlı'da Kadın Ve İktisat, Beyan Yayınları İstanbul, (25) p. 90, (32) p. 91, (34) p. 89, (42) p. 90, (62) p. $96,(65)$ p. 135.

Köksal, H. (2010), Rivayetler Işığında Hz. Peygamber Döneminde Gündelik Hayat Ve Kadın, Ankara Üniversitesi, Sosyal Bilimler Enstitüsü, Basılmamış Yüksek Lisans Tezi, Ankara, (4).

Oktar, T. (1998), Osmanlı Toplumunda Kadının Çalışma Yaşamı, Osmanlı Kadınları Çalıştırma Cemiyet-i İslâmiyesi, Bilim Teknik Yayınevi, İstanbul (35) p. 24, (36) p. 20, (45) p. 22-23, (50) p. 21, (63) p. 34, (67) p. 60, (69) p. 58-59.

Ortaylı, i. (2009), Osmanlı Toplumunda Aile, Pan Yayıncılık, İstanbul, (12) p.119.

Özbay, R.D. (2009), “Osmanlı İmparatorluğu'nda Köle Emeğinin İstihdamı ve Mükâtebe Yöntemi”, Kocaeli Üniversitesi Sosyal Bilimler Enstitüsü Dergisi (17) 2009 / 1 : 148 - 163), (43) p. 149-150, (54) p. 115.

Özbilgen, E.(2010), Bütün Yönleriyle Osmanlı Âdâb-ı Osmâniyye, İstanbul, (64) p. 464, (75) p. 464.

Özer,M. ve Biçerli, K. (2004). Türkiye'de Kadın İşgücünün Panel Veri Analizi, Sosyal Bilimler Dergisi, (5) p. 55-85.

Öztürk, S. (1994), İstanbul Tereke Defterleri (Sosyo-Ekonomik Tahlil), Osmanlı Araştırmaları Vakfı, İstanbul, (52) p. 201,

Pamuk, Ş. (1990), Osmanlı-Türkiye İktisadî Tarihi 1500-1914, İstanbul, (11) p. 32.

Quataert D., E. J. Zürcher (1988), Osmanlıdan Cumhuriyet Türkiyesine İşçiler 1839 - 1950, İstanbul, (68) p. 61,

Sahillioğlu, Halil (1981). “Onbeşinci Yüzyılın Sonu ile Onaltıncı Yüzyılın Başında Bursa'da Kölelerin Sosyal ve Ekonomik Hayattaki Yeri”, 19791980 Özel Sayısı, Ankara: ODTÜ Gelişme Dergisi: 67-138, (46) p. 111-112, (51), (52).

Sancar, A. (2010), Osmanlı Kadını Efsane ve Gerçek, Kaynak Yayınları, İzmir, (1) p.24-27, (60) p. 37.

Selmin Kangal ve vd. (1993), Çağlar Boyunca Anadolu'da Kadın, T.C.Kültür Bakanlığı Yay. Ankara, (77) p. 215.

Şer'iye Sicilleri, I ve II, Türk Dünyası Araştırmaları Vakfı, İstanbul, 1989, (31) p. 38.

Tokmakçıŏlu, E. (1991), Osmanlı Kadın Âlemleri, Geçit Kitabevi, İstanbul, (59) p. 42.

Ülkütaşır, M.Ş. (1967), “Türk Toplumunda Kadının Yeri, Hayat Tarihi Mecmuası”, Yıl.3 Mayıs, (7), p. 46-49. 


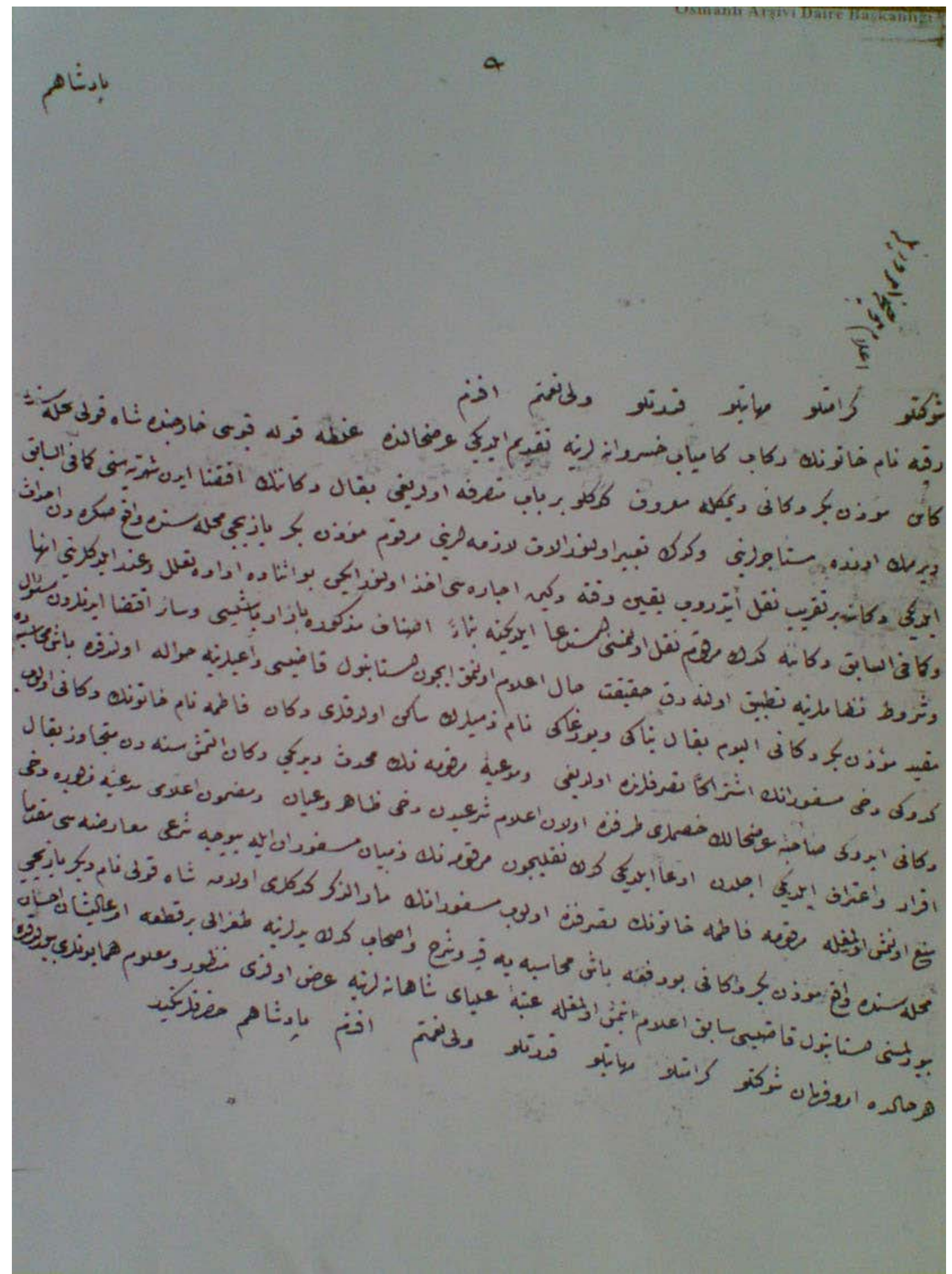

BOA, Hatt-ı Hümâyûn, nr. 14853, (1210 / 1795-1796) Galata'da Yazıcılar Mahallesi'nde bakkal dükkânı mutasarrıfı olan Fatma isimli bir hanıma ait vesika ${ }^{76}$ 


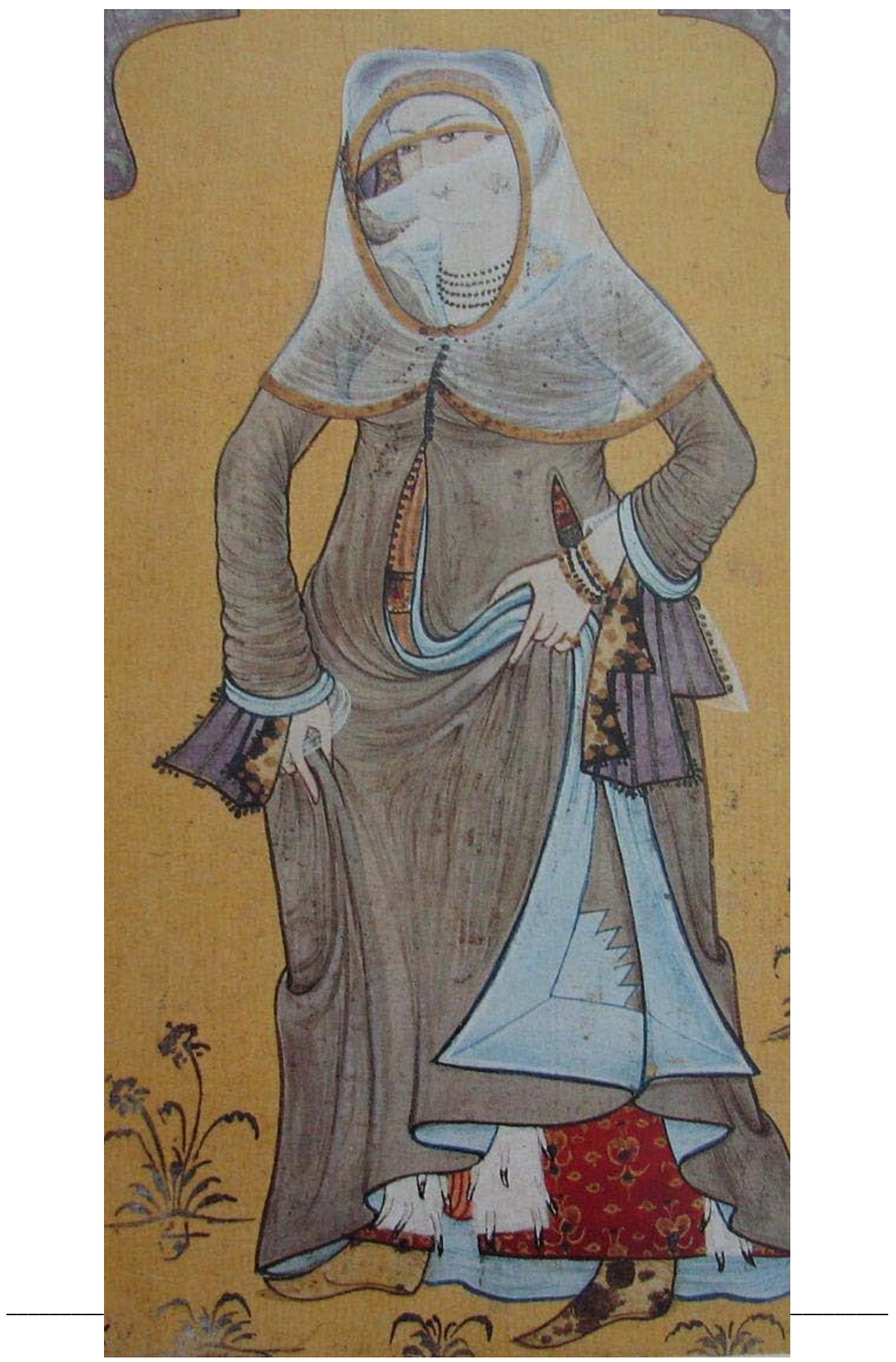




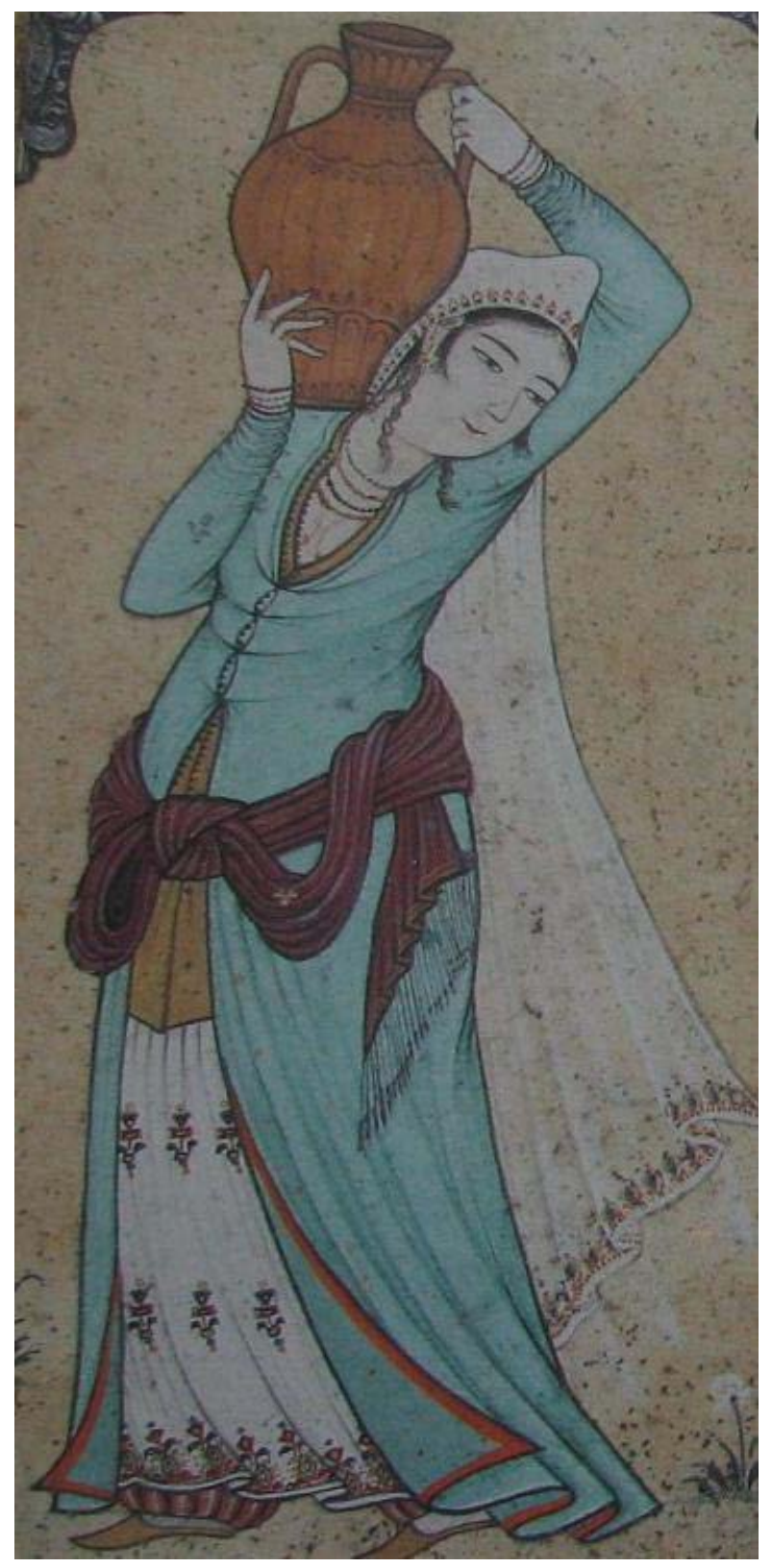

Yukarıdaki Ferâceli Kadın ile su testisi taşıyan kadın Levnî imzalı (1720-1725) 